\title{
Views of stakeholders on the application of procurement practices for the betterment of the commuter bus industry, Gauteng
}

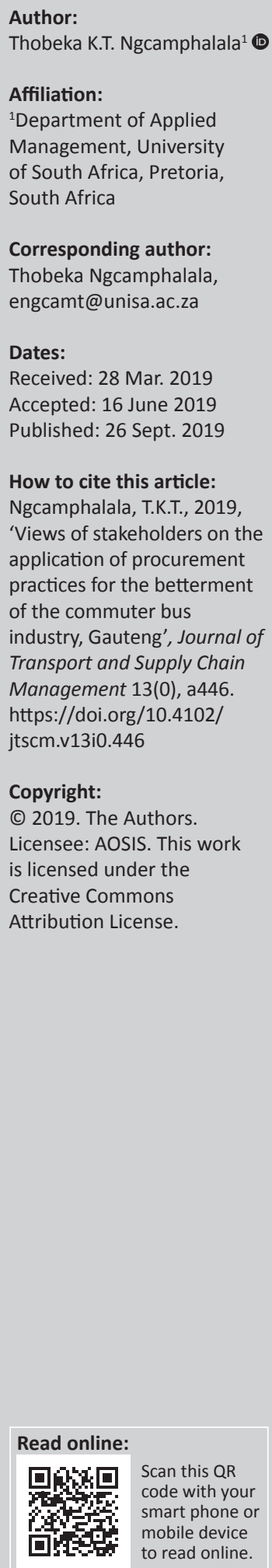

Background: In South Africa (SA), procurement is seen as a strategic tool for socio-economic development, and is guided by the Supply Chain Management Policy Framework developed in 2003. The commuter bus sector is complex and its operations are not in line with the recommended regulations. Procurement in the sector is marred by many challenges, such as the fact that no new contracts have been concluded since 2001.

Objectives: This article investigates the perceptions of key stakeholders on the application of the procurement practices within the commuter bus industry in Gauteng to improve the industry's performance.

Method: This article is descriptive and exploratory in nature and employed a mixed-method research approach. The data were collected from a sample of 18 respondents who are key stakeholders directly involved in the procurement of subsidised commuter bus services in Gauteng by means of a face-to-face interview using a semi-structured questionnaire.

Results: The findings of the article revealed that there are three procurement practices employed within the commuter bus industry, namely, interim, negotiated and tender contracts and all these are long overdue.

Conclusion: The findings of the article recommend that the key stakeholders need to select the most suitable procurement practice(s) to be employed within the industry and it highlights the challenges stemming from the lack of proper implementation of the guiding policies.

Keywords: procurement; application; South Africa; supply chain management; commuter bus industry.

\section{Introduction}

Procurement constitutes the biggest part of an institution's expenses (Dlamini \& Ambe 2013:100). It is seen as a crucial activity, whether it is for a household, an organisation or the government (Choi 2010:1). Mahmood (2010:107) states that government expenditure constitutes $18.42 \%$ of the world's gross domestic product (GDP). This function operates in an environment of increasingly intense scrutiny which is driven by technological developments and high social and political expectations (Eyaa \& Oluka 2011:35). In South Africa (SA), procurement by government constitutes 22\% of the GDP (Bolton 2016:8). According to the National Treasury (2015:3), for the period 2013/2014, the South African public sector spent R500 billion on goods, services and construction work. Similarly, within the South African public transport sector, procurement constitutes $23.4 \%$ of the GDP according to the 2014-2015 budget (Suka 2014).

The commuter bus industry is complex and its operations are not in line with the recommended regulations. Procurement in the industry is marred by a number of challenges, such as the fact that no new contracts have been concluded since 2001 (Walters \& Manamela 2016:3). In addition, the current practices favour the subsidised, commonly known as the formal, operators over the unsubsidised (informal) ones, with the former benefitting from government contracts. In addition, most of the old operators are still in the system, limiting the opportunities for new operators to successfully enter the market.

The guidance for the procurement function in this industry is found in the following policies; Constitution of South Africa (1996), the White Paper on National Transport Policy (1996), The Moving South Africa Strategy (1998), the Public Transport and Action Plan: Towards 2020 (2007) and the National Land Transport Act, 2009, however, these have not been fully implemented and 
this has led to the current operational challenges this industry is facing (Walters 2014:4). The official policy of the Department of Transport (DoT) states that any bus that requires subsidisation should be competitively tendered (Walters 2008:100). Provision is also made for negotiated contracts, for provincial and local government-owned bus companies as a once-off measure to make them financially ready for tendering. However, to date the negotiated contracts are still active. The Constitution of South Africa (1996), the Moving South Africa Strategy (1998), the Public Transport and Action Plan: Towards 2020 (2007) and the National Land Transport Act, 2009 have been implemented to a large extent, however, the White Paper on National Transport Policy (1996) has been partially implemented. Thus the status quo on the contemporary procurement practices in this industry. The lack of the proper implementation of these key policies has led to the non-alignment of bus operations with the integrated transport plans that have been developed and this hinders the growth of the industry and the country considerably. For example, there is a disagreement between the government and the subsidised commuter bus operators (stakeholders) on specific procurement practices to apply and this has added to the general dysfunctionality in the industry (Simpson et al. 2012:23). The operators prefer the negotiated contracts, for various reasons, including the fact that labour forms part of the negotiation process, which is often left out in the tender contracts, the operators retain their senior management positions and there is security on the business environment, amongst others (Walters \& Cloete 2008:1167). On the other hand, the government prefers competitive tendering because of its transparency, control over costs and room for new entrants into the market. According to the Southern African Bus Operators Association (SABOA 2015), the procurement practices employed in the industry do not meet the needs of South Africans, neither in terms of business opportunities and growth for the operators nor in terms of rendering of commuter bus services which affect the commuter services considerably. This stemmed from the shortage of funds to financially support this industry and led to operators adding unsubsidised buses to avoid overloads, which are paid for by the passenger and the operators - because they cannot claim the subsidy (Walters 2008:364). Also, because of the funds constraints, new contracts could not be concluded and eliminated the creation of business opportunities. This also, took away the right to affordable transport for the commuter. There is a huge gap between the ideal commuter bus industry and the actual operations (Munshi 2014:1). As mentioned earlier in the discussion that the official policy required that no service may be subsidised if such service is not competitively tendered, with the aim to control the budget allocated to these operations, however the tender system led to financial challenges, because the system became more expensive than anticipated. Over the last number of years, the annual budget for commuter subsidies has been inadequate to fund the level and intensity of bus operations (Walters 2010:365). For example, the DORA subsidy amount for 2009-2010 was R156 million less than the actual subsidy expenditure for 2008-2009 and $\mathrm{R} 525 \mathrm{~m}$ less than the estimated subsidy expenditure.
Also, there were major issues with organised labour regarding competitive tenders and its costing system, which led to it being opposed.

A limited number of studies have been conducted on the commuter bus industry in SA (Walters \& Manamela 2016:11; Ngcamphalala 2018; Ngcamphalala \& Ambe 2016). Most of these studies focus on policy implementation such as Walters (2014); Luke and Heyns (2013) and recent work on the procurement practices employed within the commuter bus industry in Gauteng (Ngcamphalala 2018). Following perusal of the deliberations above, a research gap was identified on the procurement practices employed within the commuter bus industry. Hence, there arose a need for this article. The article aims to understand the views of the key stakeholders on the application of procurement practices for the better performance of the commuter bus industry in the Gauteng Province.

The article makes a contribution to the body of knowledge by providing an understanding of the procurement practices employed in this industry in Gauteng. The article commences with a literature review which defines and highlights the importance of procurement in general, procurement in the South African public sector and procurement in the commuter bus industry. This is followed by an outline of the research methodology after which the findings of the article are presented. It culminates with the conclusion of the article, which also includes recommendations.

\section{Literature review}

The procurement function has different definitions. Munzhedzi (2016:2) defines procurement as the acquisition of goods and services at the best possible total cost of ownership, in the right quantity and quality, at the right time and in the right place - generally through a contract. Fourie (2015:38), on the other hand, defines procurement as a business function with an economic activity, a business process in a political system, and as a strategic profession. It can also be used as a social tool, allowing tax money to be returned to domestic residents, creating more jobs and reducing imports (Arrowsmith 1996; Fourie 2015). With procurement being a social tool, it is then funded by tax money.

According to Akafia (2007), the procurement function within governments amounts to approximately $50 \%-70 \%$ of state expenditure in Africa. Its expenditure continues to increase at a high rate (Ambe 2016:278). One of the main reasons is that this function is marred by corruption, because of factors such as: the large amounts of money involved, the presence of unsupervised discretion, budgets that may not be tied to specified goals, and payments that are not related to performance (Bolton 2006:341). According to a 2014 report of the Auditor General, unauthorised expenditure of public funds amounted to R2.9bn per year and irregular expenditure to a staggering R28.3bn whilst fruitless and wasteful expenditure rose to almost R1.8bn (Bolton 2016:26). This has led to an increase in the number of countries and/or 
organisations bestowing a strategic status on procurement in order to eliminate the mismanagement of funds and to prevent corruption within an organisation (Ambe \& Badenhorst-Weiss 2012:245). In South Africa, the government has identified public procurement as a key mechanism to achieve secondary economic objectives, such as bridging the gap between the first and second economy created by the apartheid government.

\section{Procurement practices in the South African public sector}

This section of the article reviews the procurement practices. It begins by exploring the procurement function from the perspective of the South African government and also from the perspective of the commuter bus industry.

Under the apartheid government (pre-1994), procurement practices favoured large, established companies and it was difficult for small businesses to undertake to do business with the government (Ambe 2016:279). Before the government constitutionalised procurement in SA in 1994, the State Tender Board Act governed procurement at national and provincial government levels whilst procurement at local levels was governed by various other pieces of legislation related to the procurement of goods and services (Jones 2015:11; Thai 2009). However, over time the regulations in the State Tender Board Act were amended to allow for flexibility in the procurement processes.

When the new government took power in 1994, procurement was given a constitutional status and was put under the management of the National Treasury (Ambe \& BadenhorstWeiss 2012:245). The National Treasury was given the responsibility of managing and overseeing government expenditure and they exercised overall responsibility and oversight for the public procurement policy at national, provincial and local levels. As a means of addressing past imbalances and promoting socio-economic objectives, the new government embarked on policy reforms on the procurement practices of the country (Motuba 2014:12). These were aimed at promoting the principles of good governance to enable easy access to tendering information and to provide simplified documentation. The reform practices were embedded in Section 112 of the Municipal Financial Management Act No 56 of 2003 (MFMA) and Section 76 (4) (C) of the Public Finance Management Act No 1 of 1999 (PFMA) and the Preferential Procurement Policy Framework Act No 5 of 2000 (PPPFA).

\section{Procurement practices within the commuter bus industry}

A commuter bus can be defined as a scheduled bus that is assigned for a short travel distance of 100 kilometres or less; mainly utilised by the working population as a mode of transport from their places of residence to their places of employment (Public Service Commission 2017:4). Commuter buses are used within the commuter bus industry, which falls under the auspices of the DoT and forms part of the public transport spectrum (Walters 2014:1). This section of the DoT is responsible for passenger transport, together with the train and minibus taxi industries. This industry is then further divided into municipal buses, the new Bus Rapid Transit system and subsidised and unsubsidised buses (DoT 2013). This article focuses on subsidised commuter buses.

This industry has undergone some major transformation, especially after the introduction of the National Land Transport Transition Act (NLTTA), No. 22 of 2000. This act made provision for the transition from the previous subsidy system, with the introduction of the interim and tender subsidies. Walters (2014:3) asserts that because of transformation in the South African public procurement system (White Paper on National Transport Policy 1996), reforms were initiated and competitive bidding was introduced in the procurement of commuter buses. The next section presents a brief discussion of the types of procurement practices employed within the industry.

\section{Types of procurement practices employed in the commuter bus industry}

In the commuter bus industry, the standard procurement methods that are used are based on the methods used in the general public procurement in South Africa, but adapted to the specific needs of this industry (Ngcamphalala \& Ambe 2016:7). These are the interim, tender and negotiated contracts. They came about because of labour-related issues that arose between the DoT, the industry association (the Southern African Bus Operators Association) and labour, which then led to the enacting of the National Land Transport Act of 2009. This act introduced contemporary procurement methods (negotiated and tender contracts) (Walters 2010:362). As part of the reforms, the White Paper on National Transport Policy of 1996 was introduced, which introduced the procurement of commuter bus services through competitive tendering (Walters 2014:2).

\section{Interim contracts}

This form of procurement is based on tickets sold (Walters 2010:363). Every route that an operator operated had to be approved by the DoT and it is based on distance and the travelling public's ability to pay, together with a detailed independent analysis of the operators' cost of rendering the services. Fare is determined inclusive of subsidy for the passengers on a particular route. In preparation for the tender system, the ticket-based contracts were formalised with the existing operators as 'interim contracts' (Walters \& Heyns 2012:36). Interim contracts were concluded in 1997, as an interim measure by the government to allow the existing operators the opportunity to hand back their operating permits, as part of the process to prepare for the tendering system and to help the operators become financially 'fit' (Walters 2010:362). These were the continuation of the current operations and this was a ticket-based subsidy system. Subsidies were paid according to the number of tickets sold and the costs and losses were claimed by the operator (Mosebi \& Mcdonald 2009:500). The main disadvantage of 
these contracts was their vulnerability to dishonest activities on the part of certain operators and government officials who were defrauding the system, which resulted in the government not receiving 'value for money'. The operators were claiming from the government more than what was agreed upon because of extended routes from the rising transport demand and the government could not control or budget for such operations. The higher the number of passengers transported, the more subsidy the operators claimed and this escalated the subsidy budget (SABOA 2013).

This led to the conversion of these contracts to a kilometrebased system (Walters 2014:2). The kilometre-based system allows the government to control the subsidy budget more effectively as the number of kilometres that are needed to render services are fixed and the costs related to the production of such kilometres are escalated based on an agreed escalation formula (Ngcamphalala 2018:60). Initially, the interim contracts were intended to last for 3 years but because of labour disputes in the tender contracts (for example, labour members losing some of their benefits, significant job losses and continuity of employment during the transition between interim and tender contracts) and lack of funds, the department extended the interim contracts and signed an agreement with organised labour and the Southern African Bus Operators formalising the transition arrangements (between the tender and interim contracts). From 2002 (when the moratorium on the tender system was introduced) to 2014, these contracts had been operated on a month-to-month basis as negotiated and tender contracts were managed by the DoT until the tendering issues were resolved (Sibande 2013:1; SABOA 2014:2110). Since April 2015, the month-to-month contracts have been replaced with a 3-year contract on the same terms and conditions, which expired in March 2018.

\section{Tender contracts}

This form of procurement is also referred to as the opentender system. In this form, operators prepare bids based on Parts Three and Four of the Model Tender Document (MTD) and submit such bids to the relevant authority for adjudication (Walters \& Cloete 2008:3). Labour is not part of the agreement and only becomes involved once the contract is awarded to the operator and the operator enters into labour-related negotiations with regard to employment opportunities. This is substandard because the operator cannot consult labour before accepting the contract offer and when the contract has been allocated, it is too late to negotiate any special conditions. Within the commuter bus industry, these contracts were concluded in 1997 and they followed on the challenges caused by the Interim contracts (ICs). The government had to introduce them without delay in line with the White Paper policy objectives (Walters 2010:363, 2014:2). These contracts are government controlled, with the government specifying the required services and inviting operators in an open market to tender for these services. The aims of these contracts were to encourage the participation of new entrants, to empower small operators and to enable transparent monitoring of funds for this industry. They are operated on a kilometre-based subsidy, enabling the government to budget way ahead because the travelled kilometres are fixed and are worked out on an agreed formula. These contracts enable the government to budget for their subsidy budget because kilometres to be serviced are known beforehand.

The tender contracts brought about many benefits such as enabling the government to monitor and control the rendered services through an independent monitoring firm and specify the design of the service. However, no new tender contracts have been introduced because of funding constraints. The bus subsidies increased drastically when compared with how they were prior to this system (Walters 2010:364). This was because of the fact that the operations now consisted of the 'interim contracts' and the new tender contracts, which the government had not budgeted for or anticipated, as already mentioned the interim contracts were supposed to last for 3 years but they are still in operation. Also, the used cost base is outdated and leads to a shortfall between the 'budgeted' and 'actual' operations. Over the years, the allocated subsidised bus budget has been inadequate to fund these operations. To date, no new contracts have been concluded. The tendering system lasted until 2002, when it was abandoned because of a lack of funds. Since then, these contracts have been operated on a month-to-month basis, and managed by the DoT (Sibande 2013:1). Since April 2015, the month-to-month contracts have been replaced with 3-year contract on the same terms and conditions, which as explained previously in the section on interim contracts expired in March 2018.

\section{Negotiated contracts}

This form of procurement is also referred to as single-source procurement and it is used in instances where goods or services are obtainable from only one provider. As a result of the lack of competition in this form of procurement, it is open to abuse; therefore, it should be used only in exceptional circumstances (Anthony 2012:89). It is also the least transparent type because it is not advertised and no tender procedures are conducted where all the tenderers are aware of the tender criteria. It is, therefore, advisable for organs of state to minimise the use of single-source procurement.

It is, however, suggested that this method be used where intellectual property rights are involved. This should be used cautiously and only when there is no alternative. It may be necessary to suspend a tendering process where additional and unforeseen work needs to be performed under an existing contract which cannot be separated from the main contract. This also applies to contracts where similar work must be performed under a contract that was previously awarded to the same contractor; however, a limit should be set on this. Furthermore, single-source procurement can be used where amendments have to be made to an existing contract. In the case where the nature of the amendments is such that a new contract would be advisable, a public call for tenders may be a more appropriate approach to be followed. 
Anthony (2012:73) also adds that this method is appropriate in cases of extreme urgency brought about by unforeseen events and when the time limits permitted by the tendering procedure cannot be followed.

In the commuter bus industry, this form of procurement was introduced between 1999 and 2000 through the NLTTA. Originally, it was intended to assist government-owned and municipal operators because they were financially 'unfit' to participate in competitive tendering (Walters \& Cloete 2008:1163). Later on, this Act was amended to make provision for private sector companies, albeit under certain conditions. These included small operators and previously disadvantaged persons; however, the disadvantaged person had to be a major shareholder in that company. The organisation must be operational within 24 months of the commencement of the contract and the value of the contract should not exceed a prescribed percentage of the total value of the subsidised service contracts in that area or province. This form of contract is flexible and allows bus operators to negotiate contract conditions before accepting the contractual terms (Simpson et al. 2012:23). In this contract, provision is made for the MTD issued by the DoT.

As previously explained, these contracts were operated on a month-to-month basis managed by the DoT (Sibande 2013:1). Since April 2015, the month-to-month contracts have been replaced with a 3-year contract on the same terms and conditions, which expired in March 2018.

\section{The current status on the types of procurement practices employed in the commuter bus industry}

As already discussed in the preceding sections, there are three procurement practices employed within this industry (interim, tender and negotiated contracts), which in a nutshell should not be exercised (as per the official document that requires all subsidised buses to be competitively tendered). However, because of disputes between organised labour and the DoT and because of the lack of funds, no tender contracts have been entered into. All these contracts have been on an extension from 1 to 3 months, with the last round being up to 3 years that ended in March 2018 (SABOA 2018).

Table 1 provides a summary of the status of the procurement practices employed in the commuter bus industry in SA.

\section{Research methodology}

The formal public transportation sector is led by the urban bus industry (Simpson et al. 2012:22). This industry operates approximately 13000 and 14000 buses (DoT 2003). This shows how critical this industry is to the society and the country as a whole. However, the industry is marred by a number of challenges, amongst others, limited allocation of subsidies and poor implementation of policies guiding the procurement of services (Walters 2010). This affects the choice of the most suitable procurement method. An exploration of the current procurement practices is, therefore, necessary to identify the types of procurement practices being employed and the challenges affecting the effective implementation of these methods against the guiding policies.

The research design for this article is exploratory and descriptive and makes use of a case study to provide answers to the main research question which is 'what are the differences between the applications of the different procurement practices within the commuter bus industry?' The case study method was chosen because of 'the desire to derive an up-close or (otherwise) in-depth understanding of a single or small number of cases' (Parrock 2015:7). The case study method was also selected because the article focuses on a single case and answers only one question, as mentioned above.

In response to the above objective, a mixed-method approach was selected (Creswell 2014) because the article aimed to investigate and gather an in-depth understanding of the different views in the application of the procurement practices within the commuter bus industry. This choice has also been necessitated by the fact that there is limited information available on the procurement practices employed in this industry. The procedure was conducted using both quantitative and qualitative research methods, over

TABLE 1: Current status of procurement practices within the commuter bus industry in South Africa.

\begin{tabular}{|c|c|c|c|}
\hline Types of procurement & Contract characteristic & Advantages & Disadvantages \\
\hline Interim contracts (IC s) & $\begin{array}{l}\text { - Introduced as a transition arrangement in } 1997 \text {, } \\
\text { between government and existing operators } \\
\text { - Were meant to last for } 3 \text { years initially } \\
\text { - ICs are now } 20 \text { years old } \\
\text { - Contract extensions have a duration of } \\
\text { - The months } \\
\text { - The last round of extensions was up to } 6 \text { months }\end{array}$ & $\begin{array}{l}\text { - Fare and subsidy was determined by the } \\
\text { operator } \\
\text { - On approved routes, operators were } \\
\text { allowed to increase frequencies in line } \\
\text { with ticket sales } \\
\text { - Operator could add buses to match a } \\
\text { demand, whenever necessary }\end{array}$ & $\begin{array}{l}\text { - Government had to negotiate with the operator } \\
\text { with little evidence of transparency in the } \\
\text { negotiations } \\
\text { - Awarded on ticket sales basis and were not } \\
\text { monitored. Thus increased the subsidy } \\
\text { expenditure for the government }\end{array}$ \\
\hline Tendered contracts (TCs) & $\begin{array}{l}\text { - Based on a standard contract document. Mostly } \\
\text { stand-alone services in rural or urban areas } \\
\text { - Five years originally } \\
\text { - Contract extensions have a duration of } \\
1-3 \text { months } \\
\text { - The last round of extensions was up to } \\
6 \text { months }\end{array}$ & $\begin{array}{l}\text { - Market forces determine tender price } \\
\text { - Transparent in pricing and competition } \\
\text { Presents an opportunity for new entrants } \\
\text { into the industry } \\
\text { - Area monopolies can be broken into small } \\
\text { contracts }\end{array}$ & $\begin{array}{l}\text { - Tender price reflects tender specification with } \\
\text { no room for negotiations post tender event } \\
\text { - Reduction in the number of services because } \\
\text { of government cost pressures } \\
\text { - Could result in a loss of operator expertise } \\
\text { if tenders are lost }\end{array}$ \\
\hline Negotiated contracts (NCs) & $\begin{array}{l}\text { - Mostly applicable to state-owned and } \\
\text { state-operated buses } \\
\text { - Five years originally } \\
\text { - Contract extensions are between } 1 \text { month } \\
\text { and } 3 \text { months } \\
\text { - Last round of renewals was up to } 6 \text { months }\end{array}$ & $\begin{array}{l}\text { - The transport authority can exercise more } \\
\text { control over service pricing than TCs } \\
\text { - The business plan of the operator with } \\
\text { whom negotiations take place has to } \\
\text { include other operators (i.e. subcontractors) }\end{array}$ & $\begin{array}{l}\text { - Authority has to use some form of cost } \\
\text { benchmarking to determine the price } \\
\text { - Less transparent than tendering as services } \\
\text { or costs must be negotiated } \\
\text { - NCs are with the incumbent operator in the } \\
\text { case of private operators }\end{array}$ \\
\hline
\end{tabular}


two phases. Phase 1 involved an in-depth literature review and Phase 2 consisted of a face-to-face interview questionnaire based on semi-structured questions that was conducted with government officials and commuter bus operators, with open-ended questions where the respondents had to justify their responses (a combination of quantitative and qualitative research). This provided triangulation of data.

A total of 18 respondents (12 commuter bus operators and 6 government officials) were interviewed. This population was not large enough to warrant a purely quantitative research approach. Furthermore, there is a limited amount of literature on procurement practices employed within the commuter bus industry. This lack of in-depth research on the topic identified a gap which is addressed in the present work.

Fortunately, sufficient literature is available on procurement in general. The questions in the questionnaire were guided by the literature review to address the research problem and to achieve the research objective. To understand the application of the employed procurement methods (interim, tender and negotiated contracts), the respondents were asked to indicate their experience in terms of years that they have been participating in these contracts. This was carried out to determine if these contracts are still operational and how many they are and to compare the 'ideal situation' with the 'real situation' in terms of operations. The questionnaire consisted of two questions where the respondents had to respond in order to advise on the experience they have within the operations as shown in Figure 1. The researcher recorded the respondents' responses to support their answers on the questionnaire.

The data collection was conducted by the researcher personally to maintain a close relationship and build trust

\footnotetext{
1. Please indicate the number of years that you have employed this contract within your organisation.
}

\begin{tabular}{|l|l|l|l|l|l|}
\hline Interim contracts & $0-3$ & $4-5$ & $6-10$ & $11-20$ & $\begin{array}{l}\text { Other } \\
\text { (please } \\
\text { specify) }\end{array}$ \\
\hline
\end{tabular}

Please give reasons for your answer.

2. Please indicate the number of years that you have employed these procurement practices.

\begin{tabular}{|l|l|l|l|l|l|}
\hline Tender contracts & $0-3$ & $4-5$ & $6-10$ & $11-20$ & $\begin{array}{l}\text { Other } \\
\text { (please } \\
\text { specify) }\end{array}$ \\
\hline Negotiated contracts & $0-3$ & $4-5$ & $6-10$ & $11-20$ & $\begin{array}{l}\text { Other } \\
\text { (please } \\
\text { specify) }\end{array}$ \\
\hline
\end{tabular}

Please give reasons for your answer.

FIGURE 1: Questionnaire questions on the experience of operators on the different procurement practices in the commuter bus industry in South Africa. amongst the respondents - especially, the commuter bus operators who have proven to be sceptical about government's intentions on a number of occasions, as experienced by other researchers, such as Walters and Manamela (2016:4). The collected data were analysed using both descriptive and inferential statistics through the Statistical Program for Social Sciences (SPSS, version 24). Descriptive statistics were used to describe the main features of the data in quantitative terms and inferential statistics were used to determine statistically significant differences. The qualitative open-ended responses were used to give more meaning to the respondents' views on questions, wherever appropriate (Gray et al. 2007:44).

An Independent Samples $t$-test was used to measure the differences as discussed in Section 8. The open-ended responses were used to give more meaning to the respondents' views on questions, wherever applicable (Gray et al. 2007:44). From the findings, recommendations were made to the stakeholders of the subsidised commuter bus industry.

\section{Ethical considerations}

Ethical approval for the study was obtained from the Department of Entrepreneurship, Supply Chain, Transport, Tourism and Logistics Management Research Ethics Review Committee of the University of South Africa (reference number: 2016_CEMS_ESTTL_006).

\section{Findings}

This section presents the results of the statistical analysis performed on the collected data. This includes descriptive and inferential analyses, including a discussion of the open-ended questions from the interviews in order to explain the procurement practices employed within the commuter bus industry in Gauteng. It commences by explaining the descriptive data followed by the inferential analysis and concluding with the open-ended questions analysis.

\section{Types of the procurement practices employed in the commuter bus industry}

This section highlights the different perceptions of the respondents on the application of the procurement practices. The respondents were asked to indicate their experience on different contracts within the operations. The findings on each procurement practice, respectively, are measured using the number of years, commencing with interim contacts, and then tender and negotiated contracts.

\section{Interim contracts}

With regard to interim contracts, to understand the application of these contracts, the respondents were asked to indicate their experience in terms of years that they have been participating in interim contracts. The respondents' views are indicated in Figure 1. 
As shown in Table 2, 72.22\% (13) of the respondents did not participate (no extent) in interim contracts, $27.78 \%$ (5) have 11-20 years of experience rendering these contracts, and $0.00 \%$ of the respondents have less than 10 years of experience. This demonstrates that most of the respondents do not procure by means of interim contracts so they have no experience on the negotiated contracts. However, those that did procure this way had all performed so for a lengthy period of 11-20 years. This confirms what was discovered in the literature review, that is, these contracts were an interim measure for the existing operators then (Walters 2010:362).

\section{Tender and negotiated contracts}

The tender and negotiated contracts are presented together. This is because these are the formal procurement methods recommended by the National Land Transport Act of 2009 (Ngcamphalala \& Ambe 2016:1214).

To understand the application of the tender contracts, the respondents were asked to indicate their experience in terms of years in the tender contracts. Their views are indicated in Table 3.

As shown in Table 3, $72.22 \%$ (13) of the respondents have never participated in tender contracts, $27.78 \%$ (5) have 11-20 years of experience rendering these contracts and $0.00 \%$ have less than 10 years of experience. This demonstrates that most of the respondents do not procure by means of tender contracts and thus do not have any experience regarding tender contracts. However, those that did procure this way had all performed so for a lengthy period of 11-20 years.

Furthermore, to understand the application of negotiated contracts, the respondents were asked to indicate their experience in terms of years dealing with negotiated contracts. The respondents' views are indicated in Table 4 . As shown in Table 4, 83.33\% (15) of the respondents have never had any dealings with negotiated contracts, $16.67 \%$ (3) have 11-20 years of experience rendering negotiated contracts and $0.00 \%$ have less than 10 years of experience. This demonstrates that most of the respondents do not procure by means of

TABLE 2: Length of experience of respondents participating in interim contracts.

\begin{tabular}{lccccc}
\hline Duration & $\begin{array}{c}\mathbf{0 - 3} \\
\text { years }\end{array}$ & $\begin{array}{c}\mathbf{4 - 5} \\
\text { years }\end{array}$ & $\begin{array}{c}\mathbf{6 - 1 0} \\
\text { years }\end{array}$ & $\begin{array}{c}\mathbf{1 1 - 2 0} \\
\text { years }\end{array}$ & Not at all \\
\hline Actual numbers & 0 & 0 & 0 & 5 & 13 \\
Percent of respondents & 0.00 & 0.00 & 0.00 & 27.70 & 72.22 \\
\hline
\end{tabular}

TABLE 3: Length of experience of respondents participating in tender contracts.

\begin{tabular}{lccccc}
\hline Duration & $\begin{array}{c}0-3 \\
\text { years }\end{array}$ & $\begin{array}{c}4-5 \\
\text { years }\end{array}$ & $\begin{array}{c}6-10 \\
\text { years }\end{array}$ & $\begin{array}{c}\mathbf{1 1 - 2 0} \\
\text { years }\end{array}$ & Not at all \\
\hline Actual numbers & 0 & 0 & 0 & 5 & 13 \\
Percentage of respondents & 0 & 0 & 0 & 27.7 & 72.77 \\
\hline
\end{tabular}

TABLE 4: Length of experience of respondents participating in negotiated contracts

\begin{tabular}{lccccc}
\hline Duration & $\begin{array}{c}\mathbf{0 - 3} \\
\text { years }\end{array}$ & $\begin{array}{c}\mathbf{4 - 5} \\
\text { years }\end{array}$ & $\begin{array}{c}\mathbf{6 - 1 0} \\
\text { years }\end{array}$ & $\begin{array}{c}\mathbf{1 1 - 2 0} \\
\text { years }\end{array}$ & Not at all \\
\hline Actual numbers & 0 & 0 & 0 & 3 & 15 \\
Percentage of respondents & 0 & 0 & 0 & 16.67 & 83.33 \\
\hline
\end{tabular}

negotiated contracts so they do not have any experience regarding negotiated contracts. However, those that did procure this way had all performed so for a lengthy period of 11-20 years.

In general, regarding the employment of the different types of procurement practices, only a few of the respondents are procuring in terms of these practices. However, with regard to the years of experience related to all the procurement practices, it is evident that all these contracts have been in place for over 20 years and are overdue (Sibande 2013:1; SABOA 2014:2110, 2015:3, 2016:20).

\section{Difference between the respondents on the procurement practices employed within the commuter bus industry}

This section aims to determine whether there are statistically significant differences between the respondents with regard to the various types of procurement practices employed within the commuter bus industry. The type of inferential statistical tests employed in this article were the parametric, Leven's $t$-test for equality of variances and the $t$-test for equality of means (Cooper and Schindler 2011:506). This article relied on a $95 \%$ level of confidence. A $p$-value equal or less than 0.05 implies that the results are not subject to change according to the independent sample. To address this objective, an average rating was acquired on the implementation of a specific type of procurement practice between the operators and the government officials. The types of procurement practices include interim contracts, negotiated and tender contracts. The variable 'which of the following best describes you within the commuter bus industry operations?' has values of either 1 (operators) or 2 (government officials). This functioned as the independent variable in this $t$-test.

Table 5 shows a comparison of the views between the operators and the officials on various types of procurement practices employed within the commuter bus industry. The level of statistically significant difference at a $5 \%$ level and the mean values are indicated.

Regarding the application of the interim contracts, the results indicated that the null hypothesis of equal variances assumed was rejected with a $p<0.05$ and we concluded that the variance in the ratings of operators is significantly different from that of government officials. Regarding the application of the tender contracts, the results indicated that the null hypothesis of equal variances assumed was rejected with a $p<0.05$ and again we concluded that the variance in the ratings of operators is significantly different from that of government officials.

Furthermore, the appropriate corresponding $t$-test was applied to each construct. The results of the actual Independent Samples $t$-test indicated that regarding the interim contracts, the mean difference between the operators and the government officials is statistically significant, with 
a $p<0.05$. However, the results regarding the tender contracts indicated that the mean difference between the operators and the government officials is not statistically significant with a $p>0.05$.

\section{Analysis of responses from open-ended questions}

This section provides a summary of the data acquired from the open-ended questions. It was used for triangulation to assist the researcher in reaching the final conclusions of the article.

Following the interview discussions, a theme emerged from the verbal data in response to the question on the differences in perceptions regarding the procurement practices employed in the commuter bus industry. The findings follow.

\section{Types of procurement practices employed in the industry}

Based on the conducted interviews by the researcher, it was confirmed that there were three types of procurement practices employed in the commuter bus industry, namely interim, negotiated and tender contracts. However, the majority (11) of the respondents indicated that they procured the commuter bus services by means of interim and tender contracts, whilst very few (2) of the operators procured through negotiated contracts. The respondents, believed however, mentioned that the interim, tender and negotiated contracts are long overdue and not in line with the enacted policies which state that the commuter bus service should be procured through competitive contracting (Ngcamphalala \& Ambe 2016:1218). This then means that the three procurement practices are all employed within this industry and flowing from the enacted key policies, these practices are long overdue. The industry should now be procuring as guided by the policies:

'We have been rendering the tender contracts, since 1996 and to date I am still operating. We were supposed to renew the contracts in 2001, but this was never done.' (Respondent 1, male, operator )

'We have been operating since 1997. We are the operators from the previous era.' (Respondent 3, male, operator)

Table 6 presents the storyline on the types of procurement practices employed based on data acquired via the openended questions.

\section{Conclusion}

This article investigated the perceptions of stakeholders on the application of procurement practices for the effective performance of the commuter bus sector in Gauteng. Various studies (Luke \& Heyns 2013; Walters 2014) have shown that the commuter bus industry is still facing various challenges regarding the application of the contemporary procurement practices. From the findings, it was discovered that the actual operations are in line with what was found in the literature review. Operators are stuck in the contracts that they were allocated with 17 years ago, since 2002 .

The findings of this article indicate that there are three types of procurement practices employed in the commuter bus industry. This confirms that which was gathered from the literature, namely that the contracts of interim, negotiated and tender contracts are long overdue. Walters (2010:363, 2014:2), SABOA (2015:3, 2016:20) and Ngcamphalala (2018) confirmed that these contracts have been in operation longer than the initial terms of the enacted policies guiding procurement in the industry.

TABLE 5: Significant differences with regard to the various procurement practices employed within the commuter bus industry.

\begin{tabular}{|c|c|c|c|c|c|c|c|c|c|}
\hline \multirow[t]{3}{*}{ Constructs } & \multicolumn{2}{|c|}{$\begin{array}{l}\text { Levene's test for } \\
\text { equality of variances }\end{array}$} & \multicolumn{4}{|c|}{$\begin{array}{l}t \text {-test for equality } \\
\text { of means }\end{array}$} & \multicolumn{3}{|c|}{$\begin{array}{l}t \text {-test for equality } \\
\text { of means }\end{array}$} \\
\hline & \multirow[t]{2}{*}{$\boldsymbol{F}$} & \multirow[t]{2}{*}{ Sig. } & \multirow[t]{2}{*}{$t$} & \multirow[t]{2}{*}{ df } & \multirow[t]{2}{*}{$\begin{array}{c}\text { Sig. } \\
\text { (two-tailed) }\end{array}$} & \multirow[t]{2}{*}{$\begin{array}{c}\text { Mean } \\
\text { difference }\end{array}$} & \multirow[t]{2}{*}{$\begin{array}{l}\text { Std. error } \\
\text { difference }\end{array}$} & \multicolumn{2}{|c|}{$\begin{array}{l}95 \% \text { confidence interval } \\
\text { of the difference }\end{array}$} \\
\hline & & & & & & & & Lower & Upper \\
\hline \multicolumn{10}{|c|}{ Interim contracts: Please indicate to what extent you agree with the implementation of the following procurement practices in your organisation } \\
\hline Equal variances assumed & 59.367 & 0.000 & 2.055 & 16 & 0.057 & 1.545 & 0.752 & -0.049 & 3.140 \\
\hline Equal variances not assumed & - & - & 2.605 & 10 & 0.026 & 1.545 & 0.593 & 0.223 & 2.868 \\
\hline Equal variances assumed & 9.143 & 0.008 & 1.176 & 16 & 0.257 & 0.182 & 0.155 & -0.146 & 0.510 \\
\hline Equal variances not assumed & - & - & 1.491 & 10 & 0.167 & 0.182 & 0.122 & -0.09 & 0.454 \\
\hline
\end{tabular}

Sig., significance; Std., standard error.

TABLE 6: Summary of types of procurement practices employed within the commuter bus sector

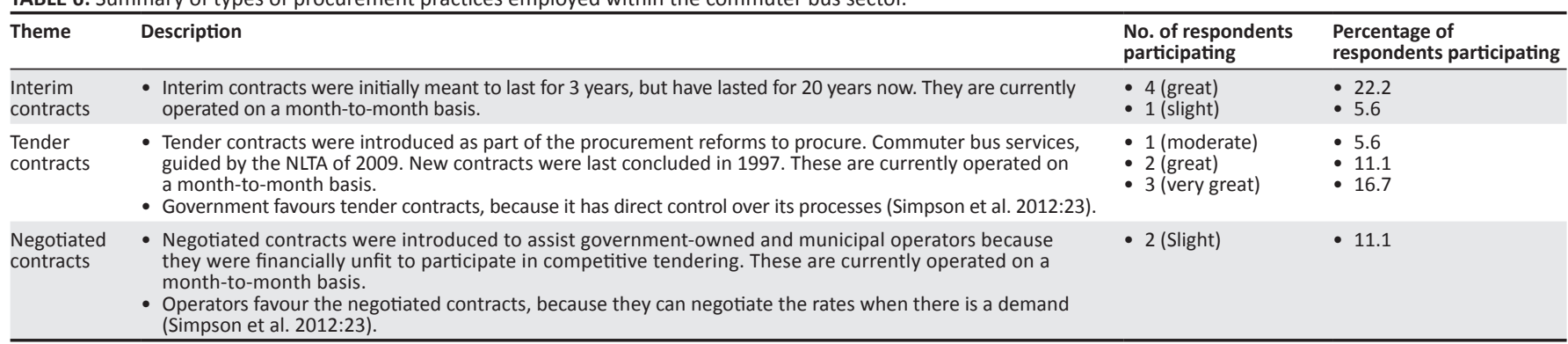

NLTA, National Land Transport Act (2009). 
As stated, the contemporary procurement practices are interim, negotiated and tender contracts. However, the majority of the respondents only procure the commuter bus services by means of interim and tender contracts whilst a few of the operators have procured through negotiated contracts.

To move forward and grow the industry, the key stakeholders in the industry need to revisit their policy formulation and implementation processes to ensure that there is proper consultation amongst the relevant parties. The government needs to continue working on its relationship with the operators. The government also needs to consider increasing the funds to improve the current operations which will make the industry financially sustainable going forward. One method of improving the finances would be to make a decision and select the procurement method stipulated in the guiding policy, which will eliminate the additional costs. Also, the monitoring firms should be strict in their monitoring and penalise operators that defraud their operational specifications, for example, overloading and missing shifts to mention a few, the government would be amazed at how much it could save this way.

\section{Acknowledgements}

The author expresses her heartfelt thanks to her supervisor, Prof. Marcus Ambe, for his motivation, support, guidance and patience throughout the study. A special thank-you to Mr Musa Maimela for statistical support, Ms Retha Burger for editing and formatting the dissertation and to all the respondents for their valuable time and information.

\section{Competing interests}

The author declares that she has no financial or personal relationship(s) which may have inappropriately influenced her in writing this article.

\section{Authors' contributions}

This article is an outcome of a master's dissertation written by T.K.T.N. T.K.T.N. is the primary and sole author of this article.

\section{Funding information}

This research received no specific grant from any funding agency in the public, commercial, or not-for-profit sectors.

\section{Data availability statement}

Data stored in accordance with institutional policy.

\section{Disclaimer}

The views expressed in this article are the author's own and not an official position of the institution or funder.

\section{References}

Akafia, M.E., 2007, 'Public procurement systems in Africa: A regional approach to reforms', Africagrowth Agenda 3(1), 10-11.

Ambe, I.M., 2016, 'Public procurement trends and developments in South Africa', Research Journal of Business and Management 3(4), 277-290. https://doi. org/10.17261/Pressacademia.2016.351

Ambe, I.M. \& Badenhorst-Weiss, J.A., 2012, 'Procurement challenges in the South African public sector', Journal of Transport and Supply Chain Management 6(1), 242-261. https://doi.org/10.4102/jtscm.v6i1.63

Anthony, A.L., 2012, 'The legal regulation of construction procurement in South Africa', Master's of Law dissertation, Stellenbosch University.

Arrowsmith, S., 1996, The Law of public and utilities procurement, Sweet and Maxwell, London.

Bolton, P., 2006, 'Government procurement as a policy tool in South Africa', Journa of Public Procurement 6(3), 193-217. https://doi.org/10.1108/JOPP-06-032006-B001

Choi, J.W., 2010, 'A study of the role of public procurement - can public procurement make society better?' 4th International Public Procurement Conference, pp. 26-28, viewed 20 March 2016, from http://www.ippa.org/IPPC4/Proceedings/13Procure mentPreferences/Paper13-4.pdf.

Cooper, D.R. \& Schindler, P.S., 2011, Business research methods, McGraw-Hill/Irwin, New York.

Creswell, J.W., 2014, Research design: qualitative, quantitative, and mixed methods approaches, 4 th edn., Sage, Thousand Oaks, CA.

Department of Transport, 2013, Annual Report 2012/2013, Department of Transport, Pretoria.

Dlamini, W. \& Ambe, I.M., 2013, 'An analysis of procurement best practices in the University of South Africa', Journal of Contemporary Management 10, 100-116.

Eyaa, S. \& Oluka, P.N., 2011, 'Explaining non-compliance in public procurement in Uganda', International Journal of Business and Social Science 2(11), 35-45.

Fourie, D.J., 2015, 'Procurement in the South African public service: A reflection of the ethical and legislative framework', Public and Municipal Finance 4(2), 38-45.

Gray, P.S., Williamson, J.B., Karp, D.A. \& Dalphin, J.R., 2007, The research imagination An introduction to qualitative and quantitative methods, Cambridge, New York.

Jones, M., 2015, 'The judicial discretion to allow unlawful procurement awards to stand: Justification and implications for the principle of legality and the rule of law', PhD thesis, University of Cape Town, Cape Town.

Luke, R. \& Heyns, G., 2013, 'Public transport policy and performance: The results of a South African public opinion poll', Journal of Transport and Supply Chain Management 7(1), 1-8, viewed from 17 December 2016, https://jtscm.co.za/ index.php/jtscm/article/view/96/104.

Mahmood, S.A.I., 2010, 'Public procurement and corruption in Bangladesh confronting the challenges and opportunities', Journal of Public Administration and Policy Research 2(6), 103-111.

Mosebi, M. \& McDonald, T., 2009, 'Application of business intelligence in South African subsidised bus companies', Proceedings of the 28th Annual Southern African Transport Conference and Exhibition (SATC 2009): Sustainable transport, Pretoria, South Africa, 6-9 July, pp. 499-506, viewed 17 December 2016, from http://www.satnac.org.za/proceedings/2008/papers/progress/Mosebi $\% 20$ No\%20109.pdf.

Motuba, L.L., 2014, 'Challenges facing the supply chain management systems of Dr Ruth Segomotsi Mompati District Municipality', MBA thesis, Northwest University, Mafikeng.

Munshi, R., 2014, 'Subsidies outdated, at companies told'. Business Day Live 07 March, viewed 09 May 2016, from www.pressreader.com/south-africa/ business-day/20140307/281535108918661.

Munzhedzi, P.H., 2016, 'South African public sector procurement and corruption Inseparable twins?', Journal of Transport and Supply Chain Management 10(1), 1-8.

Ngcamphalala, T.K.T., 2018, 'Procurement practices employed within the commuter bus industry in the Gauteng Province of South Africa', Mcom Dissertation, University of South Africa, Pretoria.

Ngcamphalala, T.K.T. \& Ambe, I.M., 2016, 'Policies and regulations guiding procurement practices in the South African commuter bus sector', Journal of Contemporary Management 13, 1204-1224.

Parrock, P., 2015, 'Mega project analysis: A case study of the Gauteng freeway improvement project', Thesis (MA), Stellenbosch University, Stellenbosch.

Public Service Commission, 2017, Public passenger transport market inquiry terms of reference, Public Service Commission, Pretoria.

Sibande, M., 2013, Bus subsidies and their impact on the taxi industry: Department of Transport briefing. Parliamentary Monitoring Group, 18 March, viewed 15 February 2017, from https://pmg.org.za/committee-meeting/15589/.

Simpson, Z., McKay, T., Patel, N., Sithole, A., Chipp, K. \& Mambo, J., 2012, Past and present travel patterns in the Gauteng City-region, Research report commissioned by the Gauteng City Region Observatory, University of the Witwatersrand, Johannesburg, South Africa.

South Africa. National Treasury, 2015, Public sector supply chain management review viewed 17 April 2016, from http://www.treasury.gov.za/publications/other/ SCMR\%20REPORT\%202015.pdf.

Southern African Bus Operators Association (SABOA), 2013, 2013/2014 annual report, viewed 29 March 2017, from http://www.saboa.co.za. 
Southern African Bus Operators Association (SABOA), 2014, 2014/2015 annual report, viewed 29 March 2017, from http://www.saboa.co.za.

Southern African Bus Operators Association (SABOA), 2015, 'SABOA Bus vehicle of communication of the southern African bus operators association, vol. 4, viewed 23 April 2017, from http://www.saboa.co.za.

Southern African Bus Operators Association (SABOA), 2016, 2016/2017 annual report to council and the AGM, viewed 17 December 2017, from http://www. saboa.co.za.

Southern African Bus Operators Association (SABOA), 2018, Southern African Bus Operators Association presentation to the Competition Commission Marke Enquiry into Public Transport, viewed 17 January 2019, from https://www.saboa. co.za/.../SABOA\%2OPRESENTATION\%20TO\%20THE\%20COMP.

Suka, L., 2014, Department of Transport on its 2014 Strategic Plan, with Deputy Minister in attendance, Parliamentary Monitoring Group, 08 July, viewed 03 February 2018, from https://pmg.org.za/committee-meeting/17288/.

Thai, K.V., 2009, International handbook of public procurement, Taylor \& Francis, New York.

Walters, J., 2008, 'Overview of public transport policy developments in South Africa' Research in Transport Economics 22(1), 98-108, https://doi.org/10.1016/j. retrec.2008.05.023
Walters, J., 2010, 'Is the bus transport contracting system in South Africa leading to a trusting relationship between contracted parties? An analysis of funding issues trusting relationship between contracted parties? An analysis of funding issues in Transportation Economics 29, 362-370. https://doi.org/10.1016/j.retrec.

Walters, J., 2013, 'Overview of public transport policy developments in South Africa', Research in Transportation Economics 39, 34-25. https://doi.org/10.1016/j. Research in Trans
retrec.2012.05.021

Walters, J., 2014, 'Public transport policy implementation in South Africa: Quo vadis?', Journal of Transport and Economics 1(8), 1-10. https://doi.org/10.4102/jtscm. v8i1.134

Walters, J. \& Cloete, D., 2008, 'The South African experience with negotiated versus competitively tendered bus contracts', Transport Research Part A 42(9), 1163-1175. https://doi.org/10.1016/j.tra.2008.05.002

Walters, J. \& Heyns, G., 2012, 'Problems with the implementation of bus transport contracting in South Africa', Journal of Transport and Supply Chain Management 6(1), 35-54. https://doi.org/10.4102/jtscm.v6i1.30

Walters, J. \& Manamela, L., 2016, 'Challenges faced by small-bus operators in participating in the formal public transport system', Journal of Transport and Supply Chain Management 10(1), 1-11. https://doi.org/10.4102/jtscm.v10i1.227 